\title{
Representation of Public Library Recreation Function in the film The Library (2015)
}

\author{
Silmi Morita \\ Study Program of Library Science \\ Faculty of Humanities, Universitas Indonesia \\ Kampus UI, Gedung VII, lt. 1, Depok 16424 \\ e-mail: silmi.morita@ui.ac.id
}

\author{
Laksmi \\ Department of Library and Information Science \\ Faculty of Humanities, Universitas Indonesia \\ Kampus UI, Gedung VII, lt. 1, Depok 16424 (+6281287787864) \\ e-mail: laksmi@ui.ac.id
}

\begin{abstract}
This thesis analyses the representation of recreation function in the film The Library (2015). This 20-minute film tells of a teenage girl who gets happiness in the library and gets a lesson about the power of love. The background of all scenes in this film are in a public library in Britain and Emily's school. This research is using semiotic method with syntagmatic-paradigmatic relation analysis by Roland Barthes. The unit of analysis is the storyline, characters, sentences or statements in each scene in the film. The result of syntagmatic analysis shows that representation of recreation function has worked well as seen from how Emily voluntarily visited library every day to read collections which made her feel love. Paradigmatic analysis shows that the background of the library is the main element that influences the feelings of the characters, such as happiness and pleasure. The conclusion is that this film contains representation of recreation function described with expressions and gestures of Emily and other characters in this film which shows that she was happy after reading the collections in this library and felt new experience that brought her happiness and how Ruth and John found their love. In
\end{abstract}


addition, this film conveys education that anyone has the same rights when they visit public library. Indirectly, this film persuasively invites audience to visit public library because they can obtain not only knowledge but also can use its library collection for entertainment and valuable experience.

Keywords: recreation function, public library representation, public library recreation function, representation of recreation function

\section{Introduction}

In many researches, public library recreation function is rarely discussed and there are more researches focusing on education and users information fulfilment function instead. Nevertheless, in addition to helping provide information and people fulfil their education and research needs, library also has to be able to make itself as recreation space. This means that a library does not only provide collection supporting education but also collection of entertainment nature. Library also has to consider all aspects to attract people's attention and make it as a recreation space.

Public library can actually be related to leisure or recreation. Recreation has always been the reason for users to use library ever since public library was introduced at the beginning of 19th century, and at the time library was visited by many for the purpose of recreation; in 1990-1991 there were 300 million adult fiction collections borrowed from public library in Britain representing $71 \%$ published adult collection. British national cultural heritage stated that the average of people visiting public library use public library for their pleasure and many of them consider library as a place for relaxation and meeting friends (Snape, 1995).

This research is conducted on film The Library (2015). This film is one of films representing public library recreation function. In this film by Jason Lamotte, library is considered as an interesting place. Library in this film is portrayed as a very comfortable, warm place and it can fulfil its users information needs. Moreover, library in this film is also described as a perfect place for a very interesting adventure. Library in this film is also depicted as 
a romantic place and make the visitors not only fall in love with the library but also find their love.

In The Library, library is portrayed as a place which does not only store educational books, but also other interesting books, such as beautiful and romantic literary works. This film describes librarian is able to help users find the books they need. Librarian in this film is not depicted as someone old and not friendly. On the other hand, librarian is depicted as someone friendly and young.

\section{Research Method}

This research is using qualitative approach. Qualitative approach is research process which captures data from the context in which an event takes place, in the effort to describe the process of events occurring, as a means of knowing the process of occurrence of an event and the perspective using induction to explain the phenomenon taking place (Gorman \& Clayton, 2005). The use of this method is because researcher would later comprehend the phenomenon referring to public library recreation function in The Library. Film is one of narrative works, thus this research is using semiotic method with Roland Barthes analysis. This method is considered appropriate to view public library recreation function in The Library (2015) by looking at the relations from storyline and main elements as well as supporting elements appearing in the film.

According to Roland Barthes, sign does not only consist of signifier and signified. Previously, Saussure has stated that in langue there are two basic relations, namely syntagmatic relation and paradigmatic relation. The relation of these two is later developed by Barthes. Syntagmatic relation is a relation arising because of the nature of linear language. Therefore, syntagmatic relation is the linkage in speech sequence which means this relation is not arbitrarily arranged but thorugh a causality rule (Zimar, 2008). This syntagmatic relation has 2 (two) categories, namely: 
a) Main function: relation among events having logical or causality which form the basis of the story

b) Catalisator: event which only serves as a complement and supporter of main function

Meanwhile, paradigmatic relation is relation among elements which dispersed and is an option. Relations which have paradigmatic relation are:

a) Index: information on characters identity, the nature, the feelings, the circumstances and their opinion (Barthes, 1966)

This research is using literature and document study as data collection technique. Primary data in this research is sentences or statements in the dialogues of The Library as well as scenes displayed in the film containing description about library. Literature and document study are the process of information collection using bibliographic works as theoretical reference, in this case, textbooks (printed and electronic), reference books, journal articles, internet websites, theses and film The Library. This research fully observes texts and images which are estimated containing library description.

In this film, library is portrayed as an interesting, peaceful and comfortable place. The impression towards library provided in this film shows the other side of library that is not only used for study and research but also as recreation space and a place to find inspiration. In this film, library is displayed as a comfortable, safe and homey place. Based on the issue, the research problem is how public library as recreation space is represented in The Library (2015)? Based on the research problem, the purpose of this research is to describe public library recreation function in The Library by understanding representation of public library recreation function displayed in the film.

\section{Theoretical Background}

W.J. Murison in his book The Public Library: its origins, purpose, and significance (1988) stated that public library has a connection with education 
institution and its function is more than supporting formal education activities. A library is a democratic organization in which everyone should be able to enjoy its services such as reading its book collections. Recreation function at library also means providing healthy activities for mind during spare time. Public library with its recreation function should be able to show hospitality, in this case embracing the whole society. A public library provides various types of collection and users are free to choose what they want to read. Library recreation function also means that public library can also inspire visitors who can never get the same benefit from universally recognized classic literature. Once again, public library provides entertainment for someone to live a happy life (Murison, 1988).

Previous research on public library recreation function in 2015 by Rifda Jilan Syahidah was Representasi Perpustakaan Umum sebagai Wahana Rekreasi Anak dalam Novel "Escape from Mr. Lemoncello's Library". The research uses semiotic method by Roland Barthes, namely syntagmatic relation on plot and storyline as well as paradigmatic relation on characters and background. Result of the research shows that Alexandriaville Public Library represents publice library performing recreation function. It is seen from various types of its collections, high technology rooms, smart librarians as well as creative and educative services for children. Novel, as a popular medium, is highly potential to change people's perspective towards public library.

\section{Results and Discussion}

The film synopsis of The Library, which is 20 minutes 32 seconds long and directed by Jason Lamotte, tells the story of Emily, a 13-year-old English student. By cycling, every day after returning from school she always stops by the public library in her area. While in the library, she received letters without senders who led her to romantic parts in old books on the shelf. She suspected the sender was one of the two male students she had always seen in the library. Finally she accidentally learned that the sender of the letter was an 80 year old grandmother, named Ruth. She found the grandmother 
was reading one part of the romantic book to her husband, John, who had dementia. Ruth tried to cure him through a collection of library books so that John recalled their experiences when they were young. The film ends with a meaningful view of Ruth to Emily.

\section{Syntagmatic Analysis}

Syntagmatic analysis expresses event sequence based on story or scene and event sequence which has causality. Knowing the plot and storyline in a film may help clarify the meaning in a film. It is especially required in this research to understand the story in this film. The focus in this research is recreation function, thus plot is important to identify how someone can voluntarily return to library, to view the activities in library, when they visit library and the reason they visit library.

\section{Chart 1. Main Function Chart}

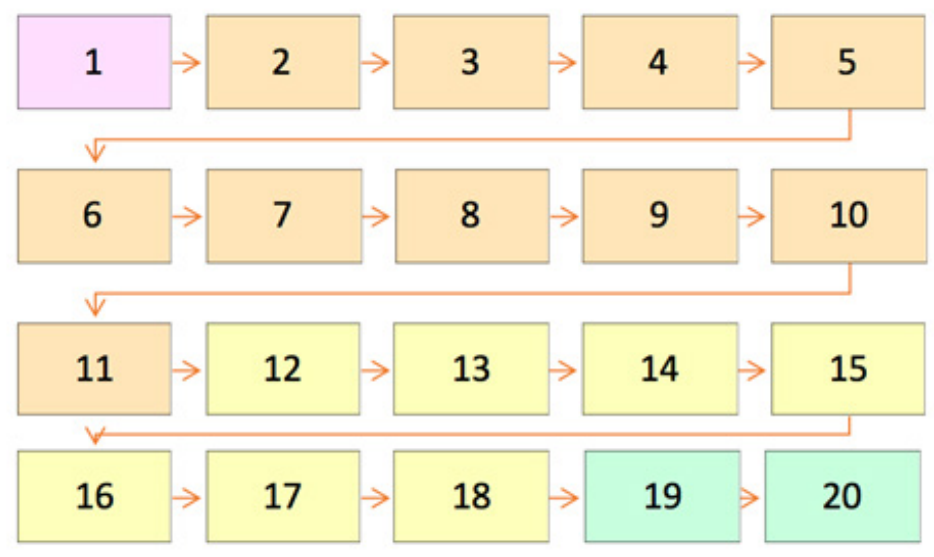

Information:

$\rightarrow \quad$ : showing causality

1-18 : showing event sequence based on story plot. Event no.1 causes event no.2 and so on.

: exposition step 
: rising action step

: climax

: resolution

Main function is relation among events having logical or causality which form the basis of the story (Barthes, 1966). Based on plot analysis, it is found that short film The Library has only one plot, which is Emily plot. In this film, the story is focused on Emily. Meanwhile, other characters are only supporting characters or conflict creators.

In storyline analysis, the story can be formed by sequencing events. The existing sequence is given single number which later explained based on story content. In the film The Library, there are 47 units of story content sequencing film scenes. This film is a short film whose all scenes are in library and related to one another in showing recreation function in public library.

The whole public library has fulfil recreation function, in terms of how library in this film is portrayed, its collection and who visits the library. Library gives comfort to its visitors and provides chairs and tables to ease its visitors to read. As seen from the visitors, this library has several permanent visitors who always came to library in their spare time. This shows that this library made visitors comfortable to stay for a longer time in the library, they even always returned to this public library.

The analysis is then conducted by looking at film plot. Main function is relation among events having logical or causality which form the basis of the story (Barthes, 1966). Based on plot analysis, it is found that short film The Library has only one plot, which is Emily plot. In this film, the story is focused on Emily. Meanwhile other characters are only supporting characters or conflict creators.

Coming home from school, Emily went to library and sat in one of spots on the 1st floor of the library to read books and working on school assignments (main function number 1). Emily took a book from a shelf and when she returned she got a letter bearing a book call number from someone 
mysterious (main function number 2). Emily asked a librarian where she could find the book and later looked for the book with that call number on the 2nd floor of the library at French drama section (main function number 3).

Emily read the book. She read the part which has been marked. The part was one of the best parts of the book (main function number 4). Emily was confused and curious about who gave her the letter knowing the content of the letter has brought her to one of romantic books (main function number 5).

The next day, Emily returned to the library after school (main function number 6). Emily paid attention to two boys in front of her, hoping to see who would give her letter, but it did not happen (main function number 7). Due to her curiosity, Emily returned to the library. Emily decided to go to the toilet to wash her face, Emily blushed and smiled remembering the poem she read (main function number 8).

Emily then returned to her place and saw a letter just like yesterday on her table. She opened the letter and read the call number written in it (main function number 9). Emily looked for and read the book which has been marked (main function number 10). She then returned to her place and drew a man and a woman holding hands (main function number 11).

The next day, she went to the library by bicycle (main function number 12). When she got there, there was a pile of books at the place where she used to sit and a woman reading (main function number 13). Emily then asked the woman if anyone was occupying the place and the books were hers, and she replied no (main function number 14).

Before sitting there, Emily removed the books in front of her (main function number 14). When she was removing the books, she found a letter just like she got yesterday and the day before. Content of the letter is certainly the same as the other day, namely a book call number different from the days before (main function number 16).

Emily walked to look for the book. Emily was confused and remained silent for a moment when she heard someone talking (main function number 
17). Emily followed the direction from which the voice came and found Ruth was helping an old man with dementia who was also her husband (main function number 18). Emily listened and watched the couple carefully until they deciced to go out from the library (main function number 19). When she was watching the couple coming out of the library, Emily saw Samuel watching her from the library bottom floor. Samuel smiled looking at Emily as if he knew what happened (main function number 20).

\section{Paradigmatic Analysis}

Paradigmatic analysis is used to analyze characteristics of the characters and some space backgrounds in the film indicating the representation of library recreation function in the film The Library. Characters analysis is conducted to understand the expression and gestures displayed by the characters. It is required to depict what is felt by characters when visiting library and what they do. The following is the analysis:

a. Emily

Figure 1. Emily



The main character in this film is Emily, a 13-year-old British teenager. Emily is a student who always visits library every afternoon after school. Emily visits library by riding her blue bicycle with blue bag and wearing a jacket every day. In the early sequence in this film, it is seen that Emily went to the library after school, indicating that she is a student. 
From how Emily took out her watch and set the time, it is seen that Emily is someone who is well-planned minded. Emily is a girl with great sense of curiosity, adventurous, brave and loves challenge. It is seen from how Emily always went to library every day, how she always read carefully every book she got. It is also reflected in the sequences which portray her receiving letters. Emily is also someone thorough from the sequence showing how she read, she always paid attention to every paragraph she read. She also paid attention carefully to the people around her. Her thoroughness is also seen when she was sharpening her pencil. Emily is also a sensitive girl, which is seen from her expression every time she finished reading every paragraph in a love poem she received. Besides that, it is seen that Emily is a neat girl from the way she wore clothes and how she tidied things every time she arrived at the library. Emily is not someone shy either, she did not hesitate to ask if she wanted to know something.

b. Ruth and John

Figure 2. Grandma Ruth and grandpa John

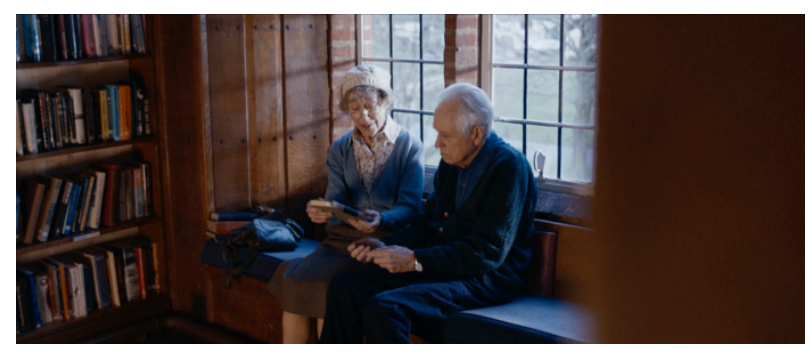

The Figure 2 shows that Ruth is a grandmother who Emily saw at the time she was riding her bicycle to the library on her first day receiving the letter. Ruth is someone who appreciates nice people around her, such as when William opened the door for her when she entered the library, she thanked him and smiled at him. Similarly, when she helped Grandpa John and how she told him story when Grandpa John and herself were young. Her soft spoken way using standard language describes that she is 
a polite and friendly person. Her gaze is always warm and friendly. In the sequence when she helped Grandpa John, it is seen clearly that Grandma Ruth is a patient person, she patiently repeated her words to Grandpa John, reminded him and helped him walk. Grandma Ruth is in 9 (nine) film sequences of The Library.

Visually, the clothes she wears portrays her as modest and calm, because she uses soft colours. The clothes she wears is small-patterned clothes describing that she likes details and loves beauty. It can be seen that she does not wear cosmetics which means that she is someone modest. She does not use glasses indicating she still has good sight. Her grey hair and wrinkled skin show that she is no longer young.

Grandpa John is Grandma Ruth's spouse. Grandpa John is someone romantic. It is known from Grandma Ruth's story about him when he was young. He used to give her the best poems in every book which he showed through letters bearing call numbers. He suffered from dementia, a disease causing brain cells to deteriorate and die faster, which can be seen from the scene when Grandma Ruth tried to help him remembering an event when they were young. Grandpa John had difficulties to understand and did not remember the event. He had to be assisted and accompanied by Grandma Ruth in all his activities.

Based on his clothes and make-up, Grandpa John looks paler than other characters which can indicate that he is the most unhealthy among others. His grey hair and wrinkled skin show that he is old. His gaze does not focus on the person to whom he talks indicating he is ill. Although it is clearly seen that Grandpa John has a disease, he is a passionate person because he still wants to live his days by walking to visit the library with his spouse.

In a film, background can be defined as space and time in which an event or activity takes place. Background can be very important in a story, especially in a film because it can describe atmosphere and show the perspective to audience. As stated by Kenney (1966), background is physical element showing where and when an event occurs. Meanwhile, according to 
Boggs (1991), background can determine characters, reflect characters; to create reality equation which gives the audience the impression of real time, place and characters' feelings; to create emotional effect; to generate great visual effect;as symbol and as microcosmos.

In this film, background analysis is conducted to show space background used in the film to support the representation of public library in the film The Library. The background of all scenes in this film are in a public library in Britain and Emily's school. The following is space background appearing in the film:

a. Exterior of Public Library Building

Figure 3. Exterior of Public Library Building

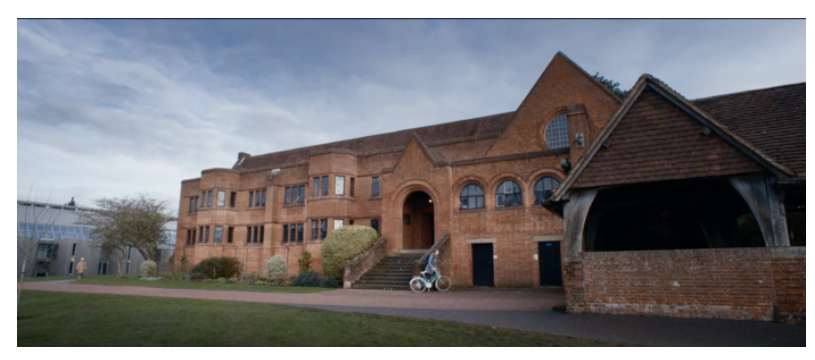

As Figure 3 shows, exterior of public library building appears two times in these film sequences. As seen in figure 10, exterior of public library building is quite large. Building exterior is only bricks and not wall. The sky is bright but a little cloudy. There is no writing or notice board bearing public library on this building. It is seen that there is no vehicle in front of this library. This background shooting is taken with long-shot and low-angle technique.

Based on the picture and the description above, it can be interpreted that this library visitors usually come by foot or bicycle, like Emily. This public library is quite large and has an extensive collection. Emily visits library in sunny afternoon. The shooting technique focuses on the library and taken from below which is performed to make the object (library) appear larger, dominant and strong. 
b. Interior of Public Library Building

Figure 4. Interior of Public Library Building

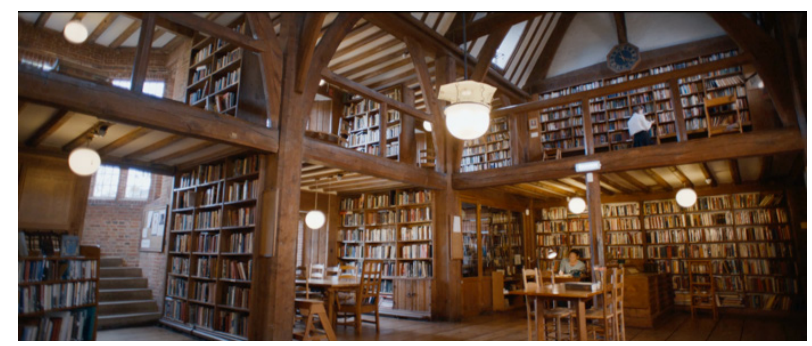

Interior of library as in figure 4 is seen in many sequences of this film. Overall, interior of this public library is made of wood by maintaning wood colour. There are several hanging lamps on during daylight. Poles, shelves, floors, cabinets and other furnitures are made of wood. Wall of this building is the same as seen from outside, only using bricks and not painted. There is a big clock on the second floor of the library. Book shelves in this library are full of varied types of book and almost none is empty. A circulation table is also seen on the first floor. In the picture, it is also seen a librarian who was working. On the second floor, Emily is seen reading a book. In this picture, the shooting of interior of library is taken with long-shot technique to focus on background, not object. The angle of shooting also used low-angle technique in order that all parts of library can fit in a frame.

Library building made of wood also made it looked more hospitable and warm in order that visitors can enjoy the comfort of library. Based on the number of shelves and collection stored on shelves, it is known that this library has numerous collection. In one figure it is shown that only Emily is in the library other than the librarian himself. That fact tells that the library is not visited by many people. This library has many chairs and tables around collection room. In the picture, it is seen that collection room and reading room are located in one place intended to ease visitors to reach collection they desire. Based on the picture, it is 
seen that the libray is very neat and clean. In the picture, it is also seen that the desired atmosphere is comfortable, warm, formal and intimate.

c. Second floor of public library

Book shelves on the second floor of the library is where Emily looked for books with call number written in every letter she received. As on the first floor, book shelves on the second floor are neatly aranged, all shelves are full and the same as other interior of the library, it is also made of wood. In the picture above, Emily is seen reading a book from the shelf in front of her; a long shelf because it is in the end corner of the library. In the picture, it is also seen tables and chairs to read.

Based on the picture, the desired atmosphere to be displayed in this sequence is warmth which is retained as in other sequences in this film, also showing how library is made as comfortable and easy as possible to access its collections as well as in aisles between every shelf, chairs and tables are provided to ease visitors to read immediately after they find the book on the shelf. This background also shows numerous collection with various subjects in accordance with the visitors' interest. Paradigmatic analysis shows that the background of the library is the main element that influences the feelings of the characters, such as happiness and pleasure.

\section{Representation of Public Library Recreation Function}

The type of library appearing in the film The Library is public library. In this film, the type and name of library are not known, but as seen from its collection, location and visitors, it is one of public libraries in Britain. Usually, a public library has varied collection from various fields of sciences. As the name suggests, visitors of a public library also come from a variety of backgrounds and ages, as seen in the film The Library. In this film, it is seen that library does not limit itself to anyone who comes, including someone with disabilities. It is seen in this film that library becomes a safe and comfortable place for anyone. This library is equipped with reading room which is also collection room because overall this library has chairs and tables between its shelves. 
In this film, plot and story line can show how story goes from the beginning when Emily visited the library and what motivated her to visit it. In plot and story line, it is also seen what she got from visiting the library. Meanwhile, from the characters present in this film, it can be seen that the library is open for public and hospitable for elderly or youngsters. The existing background supports plot and story line to establish atmosphere to be displayed in the film. This means that every aspect in this film influences representation of library being told.

In a broad sense, a public library plays important role in encouraging its visitors to visit library voluntarily and encouraging people to visit library in their spare time (Snape, 1995). It is seen in several of this film sequences that Emily visited the library after school.

As a place which has recreation function, a public library should be visited by anyone and from any background. In this film, it is especially depicted clearly that anyone can visit the library. It is seen in various sequences in this film whose overall story occured in public library.

Another thing that can depict recreation function in public library and that displays it the most is how public library along with its contents are able to impact on people, either individually or in groups. A library should be able to give constructive effect to someone, increase happiness, give good influence, be inspiration, increase creativity and improve moral by strengthening oneself intellectually (Murison, 1988). Overall, the description which this film would like to convey is how public library can bring happiness, bring Emily into a very different adventure; how a library collection and everything inside public library can give her happiness and excitement.

Recreation can benefit especially to increase welfare and survival. Public library offers recreation to help increase welfare. Relaxation and emotion stabilization through reading have been recognized since long ago, as written by Murison (1988), but in several cases, benefit of reading can be more than that. For someone in depression, reading can be one of the ways to heal it, and to some people, reading can be a better way than 
medical treatment (Hayes \& Morris, 2005). In this film, it is depicted how public library is able to increase welfare and survival, especially seen clearly in sequences showing Ruth and John.

Social quality of a person is recognized by psychologists as one of key factors to increase welfare. Benefit of recreation is as an offer to socialize with the people around us. Library helps someone socialize by providing place for individuals to meet and gather (Hayes \& Morris, 2005). In this film, public library is depicted as able to be a media for people to socialize as shown in several of this film sequences.

The entire story of this film represents public library universally, which is conveyed well and depicted well both visually and by audio. Public library recreation function is very much visible in the whole set of stories from how Emily started her adventures in the library indirectly when she received letters containing book call numbers.

\section{Conclusion}

This research of representation of Public Library recreation function in the film The Library (2015) found that the film representing public library with its recreation function is able to make it into a place of fun and brings welfare to its visitors. The appearance of this recreation function is clearly visible when Emily started to receive letters containing call numbers from someone unknown. Various types of collection available in library, how library is able to give positive impact to someone, and how the library is physically able to describe library recreation function, namely library plays an important role in encouraging its use for recreation purpose and leisure activities by providing reading materials in Public Library Manifesto (IFLA/ UNESCO, 2001.

This recreation function is represented entirely in the whole set of stories in this film. It is also seen in every thing performed by Emily. Every sequence of this film describes recreation function in public library. In such sequences as when Emily read her book and then smiled. It is clearly seen 
that how public library collection can make its visitors feel happiness. This is also seen in the next days when Emily, Samuel and William visited the library which means they felt comfortable to be in the library during their spare time. It is also seen in the sequence in which Ruth spoke to John about how they found their love in public library.

Library is a rare thing to see in films, moreover film with library theme. This film describes a different picture about library. Public library in films usually depicting it as a place to study, boring, dark with unfriendly librarian is not seen in this film. In this film, recreation function is more prominently depicted than any other public library's functions. Library is represented as a very hospitable place for anyone, has entertainment collection for comfort and family and can bring happiness to its visitors.

Recreation function shown in this film does not only indicate recreation function for entertainment but also educative recreation function and therapeutic recreation function. This educative recreation function is seen from how Emily could enrich herself with collections she read in her every voluntary visit. Meanwhile, therapeutic recreation function is seen from how Ruth always accompanied and helped John visiting library to restore his memory.

In addition, this film conveys education that anyone has the same rights when they visit public library. Indirectly, this film persuasively invites audience to visit public library because they can obtain not only knowledge but also can use its library collection for entertainment and valuable experience.

\section{Aknowledgement}

This work was supported by funding from 2018 Indexed International Publication for Students' Final Assignment (PITTA) Grant, Universitas Indonesia. 


\section{References}

Astuti, L. D. Representasi Perpustakaan Keliling dalam Film Televisi Kidung Tumirah, Depok: FIB UI, 2013.

Azzasyofia, Mira. Representasi Perpustakaan dan Pustakawan dalam Film The Librarian: Quest for The Spear, Depok: FIB UI, 2012.

Barthes, R. Introduction à l'analyse structurale des récits, Paris: Edition du Seuil, 1966.

Boggs, J. The Art of Watching Films. California, USA: Mayfield, 1991.

Gorman, G. E., \& Clayton, P. Qualitative Research for The Information Professional: A Practical Handbook (2 ed.). London: Facet Publishing, 2005.

Hall, S. Representation: cultural representations and signifying practices. London: Thousand Oaks, 2003.

Hayes, E., \& Morris, A. “Leisure Role of Public Libraries: User Views.” Journal of Librarianship and Information Science, 37, No. 3 (2005, September): 131-139.

Hoed, B.H. Strukturalisme dan Perkembangannya. Slide Presentasi Kelas Teori Kebudayaan untuk Magister UI, Depok: Universitas Indonesia, 2010. . Semiotik dan Dinamika Sosial Budaya, Depok: Komunitas Bambu, 2011.

IFLA. The Public Library service: IFLA/UNESCO Guidelines for Development, Munchen: Saur, 2001.

Iskandar, R. M. Representasi Gemar Membaca dalam FIlm Seputih Hati Kintan, Produksi Perpustakaan Nasional Republik Indonesia, Tahun 2006. Depok: FIB UI, 2014.

Juliastuti, Nuraini. Representasi. KUNCI, edisi 4, 6. , 2000.

Kurniawan. Semiologi Roland Barthes, Magelang: Yayasan Indonesiatera, 2001.

Laksmi. Tinjauan kultural terhadap kepustakawanan: inspirasi dari sebuah karya Umberto Eco, Depok: Fakultas Ilmu Pengetahuan Budaya, 2006. Murison, W.J. The Public Library: its origins, purpose, and significance, Great 
Britain: Clove Bingley Limited, 1988.

Paramita, K.W. Gambaran Perpustakaan dalam Cerita Harry Potter, Depok: FIB UI, 2009.

Pratista, H. Memahami Film, Yogyakarta: Homerian Pustaka, 2008.

Snape, R. “Recreation.” In R. Snape, Leisure and The Rise of Public Library, London: Library Association Publishing, 1995.

Syahidah, R.J. Representasi Perpustakaan Umum sebagai Wahana Rekreasi Anak dalam Novel "Escape from Mr. Lemoncello's Library". Depok: FIB UI, 2015.

Terras, M. Review of G.E. Gorman and P. Clayton "Qualitative Research for the Information Profession: A Practical Handbook". Literary and Linguisctic Computing, 22 (2007): 246-248.

Eco, U. and William, W. In The Name of Rose, New York: Warner Books, 1980. Zaimar, O.K. Hubungan Sintagmatik dan Paradigmatik. In O.K. Zaimar, Semiotik dan Penerapannya dalam Karya Sastra, Jakarta: Pusat Bahasa Departemen Pendidikan Nasional, 2008. 